\title{
Farklı oranlarda alüminyum köpük takviyeli çarpışma-kutularının mekanik performanslarının karşılaştırılması
}

\author{
Betül GÜLÇİMEN ÇAKAN *, Cihat ENSARİOĞLU, M. Cemal ÇAKIR \\ Uludă̆ Üniversitesi, Mühendislik Fakültesi, Makina Mühendisliği Bölümü, Görükle kampüsü, Bursa \\ Geliş Tarihi (Recived Date): 23.05.2018 \\ Kabul Tarihi (Accepted Date): 06.12.2018
}

\section{Özet}

Çarpışma-kutuları otomobillerde, kaza anında çarpışma enerjisini sönümleyerek aracın ve yolcuların en az zararı almasını sağlayan önemli elemanlardır. Bu çalışmada, öncelikle, alüminyum köpük malzemesinin yarı-statik basma testleri gerçekleştirilerek malzeme modeli oluşturulmuştur. Bu malzeme modeli; farklı oranlarda alüminyum köpük takviyesi yapılmış çarpışma-kutularının mekanik performansını, boş çarpışmakutularınınki ile karşılaştırmak amacıyla, sanal çarpışma analizlerinde kullanılmıştır. Köpük takviyeli çarpışma-kutularının, köpük oranıyla artacak şekilde; plato kuvveti, çarpışma süresi, deformasyon davranışı ve enerji emilimi yönünden daha üstün olduğu görülmüsşürr.

Anahtar kelimeler: Alüminyum köpük, çarpışma-kutusu, darbe enerjisi emilimi, sonlu elemanlar yöntemi.

\section{Comparison of mechanical performances of the crash-boxes filled with various percentages of aluminium foam}

\begin{abstract}
In this study, firstly, compression tests of aluminium foam material were carried out to determine its constitutive material model. This model was then utilized in virtual crash tests of crash-boxes filled with various percentages of aluminium foam. The results were compared with those of the empty crash-boxes to evaluate their mechanical performances. It was observed that the foam-filled crash-boxes exhibited superior

\footnotetext{
* Betül GÜLÇİMEN ÇAKAN, bgulcimen@ uludag.edu.tr, https://orcid.org/0000-0003-1739-1143

Cihat ENSARİĞLU, cihatensari@uludag.edu.tr, https://orcid.org/0000-0003-2843-9536

M. Cemal ÇAKIR, cemal@uludag.edu.tr, https://orcid.org/0000-0003-0816-4029
} 
properties of plateau force, impact duration, deformation behaviour and energy absorption, which get better by the increasing foam percentage.

Keywords: Aluminium foam, crash-box, impact energy absorption, finite element method.

\section{Giriş}

Otomotiv endüstrisinde kullanılan çarpışma-kutuları pasif güvenlik sistemi elemanı olarak yolcu güvenliğini sağlama ve aracın ana yapısını korumada önemli bir yere sahiptir. Genel olarak ince cidarlı yapılar olarak karşımıza çıkan bu elemanlar, çarpışma enerjisinin önemli bir kısmını emerek çarpışma kuvvetini önemli ölçüde azaltmaktadır [1, 2].

2000'li yılların başında, çoğu çarpışma-kutusu, (düşük karbonlu çelik sınıfında olan) derin çekme çelikleri ile imal edilirken; yüksek mukavemetli çeliklerin, alüminyum alaşımlarının, magnezyum alaşımlarının veya polimer malzemelerin bu alanda kullanılacağg konuşulmaktaydı [3]. Günümüzde ise çarpışma-kutuları için, genelde düşük karbonlu çelikler ve alüminyum alaşımları kullanılmaktadır [4].

Günümüze kadar çarpışma-kutuları, geometrik parametreleri ve yapıldığı malzeme açısından incelenmiş olsa da; son yıllarda çarpışma-kutularının metal köpük ve özellikle alüminyum köpük ile takviye edilmesi, dikkat çeken konular arasına girmiştir [5-7]. Alüminyum köpük malzemeler; saf alüminyumun veya alüminyum alaşımının, genellikle köpürtücü ajan kullanılarak ergime sıcaklığının üzerinde gözenekli hale getirilmesiyle üretilen malzemelerdir [8, 9]. Düşük yoğunluk, yüksek mukavemet, yüksek enerji emilimi gibi özelliklere sahip olmasi; otomotiv üreticilerinin dikkatini bu malzeme üzerine çekmiştir. Üreticiler, özgül mukavemeti yüksek ve yüksek enerji emilimine sahip konstrüksiyonlar elde etmek için bu yöndeki Ar-Ge çalışmalarına yönelmişlerdir.

Otomotiv sektöründe yaygın kullanımı, yüksek enerji emme kapasitesinden dolayı çarpışma-kutuları olmakla beraber araçlarda farklı kullanım noktaları da mevcuttur. Örneğin yan çarpışma durumunda güvenliği arttırmak için kapı içi çubuklarda (antiintrusion bars) veya araç tavan sütunlarında (A, B pillars) kullanımı göz önüne alınmıştır [10]. Köpük metal uygulamaları, raylı taşıtlarda ve gemilerde de yapısal elemanları hafifletme amacıyla kullanılması öngörülmekte ve bu amaçla prototip çalışmaları yapılmaktadır. [11,12]. Köpük metallerin farklı kullanım alanları yaygınlaştırmak amacıyla nümerik çalışmalar da önem kazanmıştır. Nümerik modellerde kullanılmak üzere, köpüklerin yarı-statik ve dinamik basma davranışının belirlenmesi gerekmektedir [13-15].

Bu çalışmada; farklı oranlarda alüminyum köpük takviyesi yapılmış alüminyum çarpışma-kutularının çarpışma performansı, alüminyum boş çarpışma-kutularının performansı ile karşılaştırılmıştır. Karşılaştırılan özellikler; plato kuvveti, çarpışma süresi, deformasyon davranışı, enerji emilimi ve özgül enerji emilimini kapsamaktadır. 


\section{Materyal ve yöntem}

\subsection{Alüminyum köpü̈̆̈̈̈n üretilmesi}

Kapalı gözenekli alüminyum AluPam A.Ș. (Türkiye)'den temin edilmiștir. Köpük metalin üretimi ergiyik yöntem ile gerçekleştirilmiştir. Ana malzeme olarak saf Al içerisine $\mathrm{SiC}$ ve $\mathrm{MgO}$ alaşım elementleri ilave edilmiş ve $\mathrm{CaCO}_{3}$ ajanıyla köpürtülmüştür. Üretilen köpük metalin ortalama yığın yoğunluğu $0,414 \mathrm{~g} / \mathrm{cm}^{3}$ olarak belirlenmiştir. $\mathrm{Bu}$ değer, boyutları bilinen numunelerin kütlelerini hacimlerine bölerek elde edilmiştir [9].

\subsection{Alüminyum köpüğ̈̈̈n basma testleri}

Alüminyum köpügün basma testleri, ISO 13314 Gözenekli ve Hücre Yapılı Metaller için Basma Testi Standardına uygun şekilde gerçekleştirilmiştir [16]. Buna göre aynı yönde (köpürtme ve çarpışma yönü) 5 adet $30 * 30 * 30 \mathrm{~mm}^{3}$ boyutlarında numune (Şekil 1) hazırlanmıştır. Bu numuneler $20 \mathrm{~mm} / \mathrm{dk}$. hızda (yaklaşık olarak 0,011 s ${ }^{-1}$ deformasyon hızında) basılmıştır.

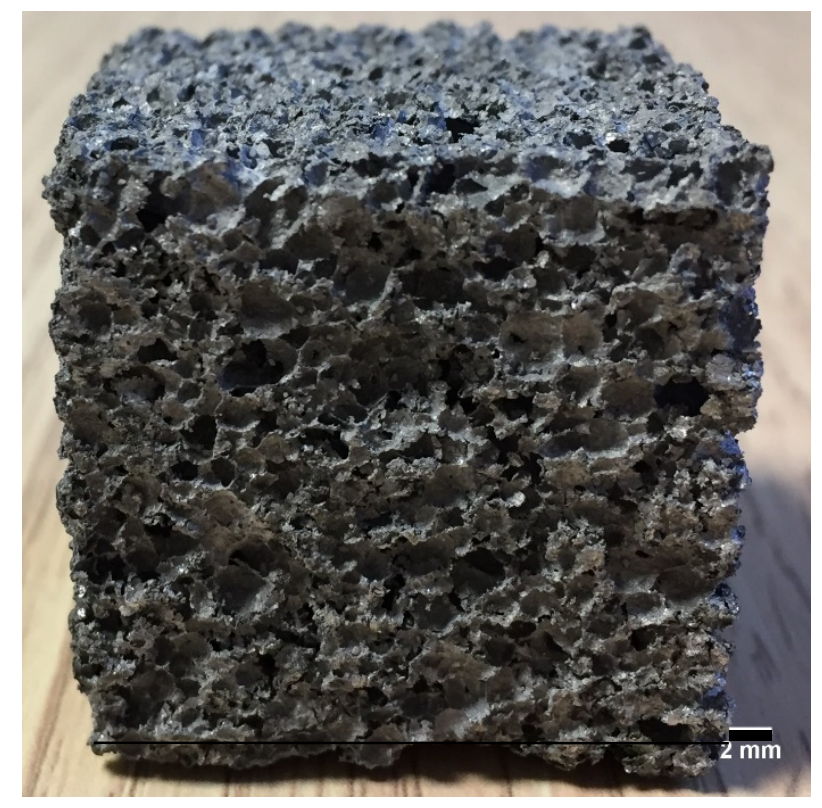

Şekil 1. Alüminyum köpük basma testi numunesi.

\subsection{Malzeme modeli}

Alüminyum köpüğün modellenmesi için Abaqus içerisinde yer alan Deshpande-Fleck izotropik plastisite modeli kullanılmıştır $[17,18]$. Bu modele akma gerilmesi aşağıdaki analitik formülle ifade edilmektedir:

$\sigma_{y}=\sigma_{p}+\gamma \cdot \frac{\hat{\varepsilon}}{\varepsilon_{D}}+\alpha_{2} \cdot \ln \left(\frac{1}{1-\left(\frac{\hat{\varepsilon}}{\varepsilon_{D}}\right)^{\beta}}\right)$.

Burada; $\hat{\varepsilon}$ eşdeğer gerinme, $\sigma_{p}, \gamma, \alpha_{2}$ ve $\beta$ malzeme sabitleridir. Yoğunlaşma noktası $\left(\varepsilon_{D}\right)$ ise, aşağıdaki formül ile köpük malzemenin yoğunluğunun $\left(\rho_{f}\right)$, alüminyumun yoğunluğuna $\left(\rho_{f 0}\right)$ oranı kullanılarak elde edilmektedir. 
$\varepsilon_{D}=-\ln \frac{\rho_{f}}{\rho_{f 0}}$.

\section{Sonuçlar ve tartışma}

\subsection{Basma testi sonuçları}

Basma testleri sonucunda, Şekil 2a'da görülen, alüminyum köpügün kuvvet-uzama eğrileri elde edilmiştir ve bu değerler gerilme-gerinme değerlerine dönüştürülmüştür (Şekil 2b). Köpük malzemenin homojen olmayan gözenek yapisından dolayı, numunelerin yoğunlukları değişebilmektedir. Şekil 2'de görüldüğü gibi mekanik özellikler yoğunluğa bağlı olarak değişmekte yani yoğunluk arttıkça kuvvet/gerilme değerleri yükselmektedir. Bu sebeple, genel davranışı temsil eden ortalama test eğrisi belirlenmiştir.
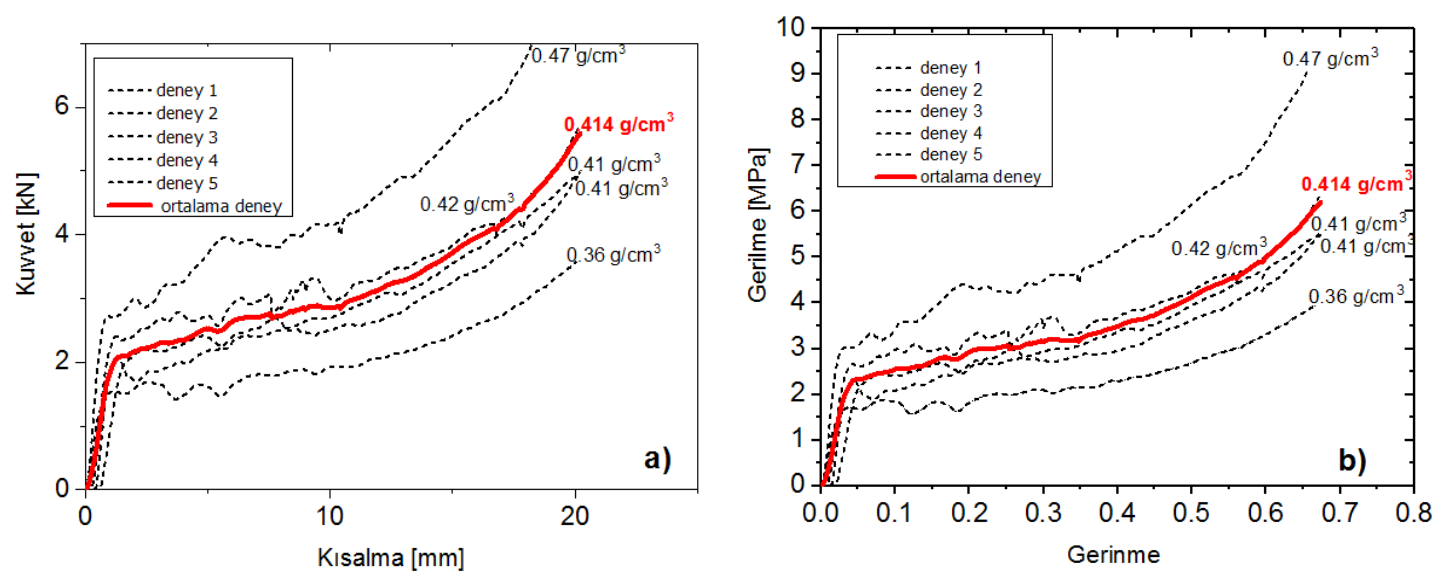

Şekil 2. Basma testine ait deneysel

a) kuvvet-uzama ve b) gerilme-gerinme eğrileri.

Şekil 3'te alüminyum köpüğün basma testinden elde edilen gerilme-gerinme eğrisi üzerinde, köpük malzemelere özgü 3 karakteristik bölge gösterilmiştir. Genel olarak köpük malzemeler; yapıldığı malzeme, yoğunluk ve gözenek tipine (açık veya kapalı) bağlı olarak oransal olarak değişse de bu karakteristik bölgeleri göstermektedir. Burada ilk lineer bölge, köpüğün elastik davranış gösterdiği kısımdır. Bu bölgede hücre duvarları elastik uzama ya da kısalma şeklinde deformasyona uğramaktadır. Lineer elastik bölgenin bitimiyle beraber, plastik olarak katlanma (deformasyon) başlamakta ve gerilmenin neredeyse sabit olarak devam ettiği bir plato bölgesi boyunca devam etmektedir. Köpüğün daha fazla sıkıştırılamadığı bir gerinme değerine (yoğunlaşma gerinmesi) gelindikten sonra, köpük neredeyse ana malzeme (hücre duvarlarını oluşturan malzeme) gibi davranmakta ve gerilme değeri hızlı bir şekilde artmaya başlamaktadır [8]. 


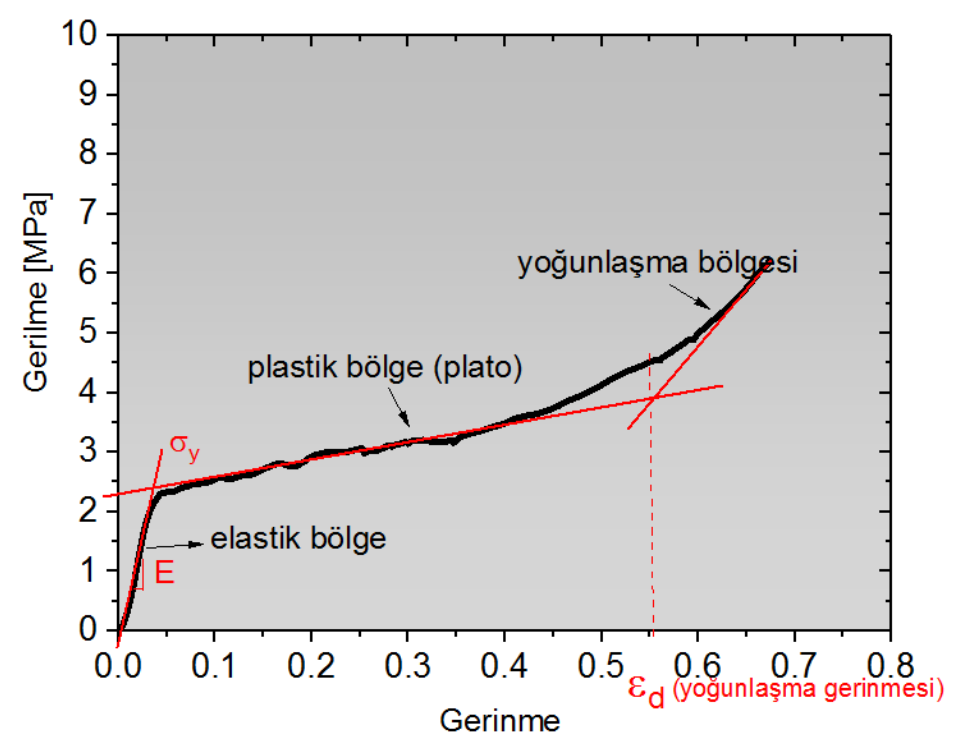

Şekil 3. Alüminyum köpüğün basma etkisi altında gösterdiği farklı deformasyon bölgeleri.

\subsection{Basma testine ait deneysel ve nümerik sonuçların karşılaştırılması}

Abaqus içerisinde yer alan crushable foam plasticity modeli alüminyum köpügün malzeme modellemesi için kullanılmıştır. Deshpande-Fleck'in teorik modeline dayanan bu malzeme modelinin, izotropik ve hacimsel pekleşme seçenekleri bulunmaktadır. Basma davranışının baskın olduğu durumlarda her iki model yakın sonuç verdiği için, izotropik pekleşme seçeneği tercih edilmiştir.

İzotropik pekleşme için basma akma gerilmesi oranı $(\mathrm{k})$, analiz programına girilmesi gereken malzeme sabitlerindendir. Bu değer; tek eksenli basma testindeki ilk akma gerilmesinin, hidrostatik basma testindeki ilk akma gerilmesine oranına eşittir. Abaqus kullanım kılavuzunda bu parametrenin değerinin 0-3 arasında değiştiği belirtilmiştir [18]. Hidrostatik basma testi verisi olmaması sebebiyle, bu değer tahmin edilmek zorundadır. Literatürdeki [9] kısıtlı deneysel verilerden yola çıkılarak, alüminyum köpüğün tek eksenli ve hidrostatik basma testlerinden elde edilen gerilme-gerinme eğrileri arasında önemli bir fark olmadığ belirtilmiştir. Bu sebeple, her iki ilk akma gerilmesi değerinin eşit olduğu düşünülerek $\mathrm{k}$ değeri 1 olarak alınmıştır. Yine de yapılan analizlerde 0-3 arasında farklı k değerlerinin, nümerik sonucu neredeyse etkilemediği gözlemlenmiştir [19].

Plastik bölge için, akma gerilmesinden sonraki gerçek gerilme-gerinme değerlerinin tablo şeklinde Abaqus'e girilmesi gerekmektedir. Ashby ve arkadaşları'na göre; köpügün akma gerilmesi, eğer varsa ilk en üst gerilme değeri; aksi halde, lineer kısım ile plato kısmına çizilen eğim çizgilerinin kesişimindeki gerilme değeri olarak alınmalıdır. Şekil 3'te görüldüğü gibi, ikinci tanıma uygun olarak ortalama eğri üzerinden akma gerilmesi belirlenmiştir.

Alüminyum köpük malzeme sıkıştırıldığında yanal yönlerde neredeyse hiç uzama olmadığı varsayıldığından plastik Poisson oranı 0 olarak alınmıştır. Elastisite modülü ise lineer bölgenin eğiminden hesaplanmıştır. Elastik Poisson oranı birçok Alüminyum köpük için 0,3 olarak belirtildiği için bu değer kullanılmıştır. 
Tablo 1'de köpük malzemenin modellenmesinde kullanılan malzeme özellikleri verilmiştir.

Tablo 1. Kullanılan köpük malzemenin, elde edilen mekanik özellikleri.

\begin{tabular}{|l|c|}
\hline Yoğunluk $\left[\mathrm{g} / \mathrm{cm}^{3}\right]$ & 0,414 \\
\hline Elastisite modülü $[\mathrm{MPa}]$ & 67 \\
\hline Elastik Poisson oranı $\left(v_{\mathrm{e}}\right)$ & 0.3 \\
\hline Plastik Poisson oranı $\left(v_{\mathrm{p}}\right)$ & 0 \\
\hline Akma gerilmesi $\left(\sigma_{\mathrm{y}}\right)[\mathrm{MPa}]$ & 2 \\
\hline Basma akma gerilmesi oranı $(\mathrm{k})$ & 1 \\
\hline
\end{tabular}

Alüminyum köpük malzemenin basma testine ait nümerik kuvvet-kısalma eğrileri, Șekil 4'te deneysel eğri ile birlikte verilmiştir. Köpüğün modellenmesi için gerçek gerilmegerçek gerinme değerlerinin kullanılması durumunda, plato bölgesinin ilerleyen kısımlarında başlamak üzere, deneysel ve nümerik eğriler ayrışmaya başlamaktadır (Şekil 4, nümerik 1 eğrisi). Köpüğün Poisson oranının neredeyse 0 olması sebebiyle; basma esnasında anlık kesit alanı ilk kesit alanına, dolayısıyla gerçek gerinme ise nominal gerinmeye (mühendislik gerinmesine) eşit olacaktır. Bundan yola çıkarak, pekleşme eğrisi için gerçek gerilme-gerçek gerinme yerine, nominal gerilme-gerçek gerinme değerleri kullanılmış ve bu değerlerin deneysel sonuca daha yakın olduğu görülmüştür (Şekil 4, nümerik 2 eğrisi). Abaqus, tanımlanmış olan gerilme-gerinme değerlerinin üstündeki değerlerin ekstrapolasyonunda, en son hesaplanmış eğimi kullanmaktadır. Bu sebeple, Abaqus'e girilen plastisite datası yoğunlaşma bölgesini de içerirse ekstrapolasyon için kullanılan eğim yüksek olmakta; bundan dolayı, son bölgede, deneysel eğridekinden daha yüksek gerilme değerlerine çıkılmaktadır. Yoğunlaşma bölgesini içermeyen pekleşme eğrisi datası Abaqus'e girilince elde edilen nümerik eğrinin (Şekil 4, nümerik 3 eğrisi), deneysel eğriyle en uyumlu sonucu verdiği görülmüștür.

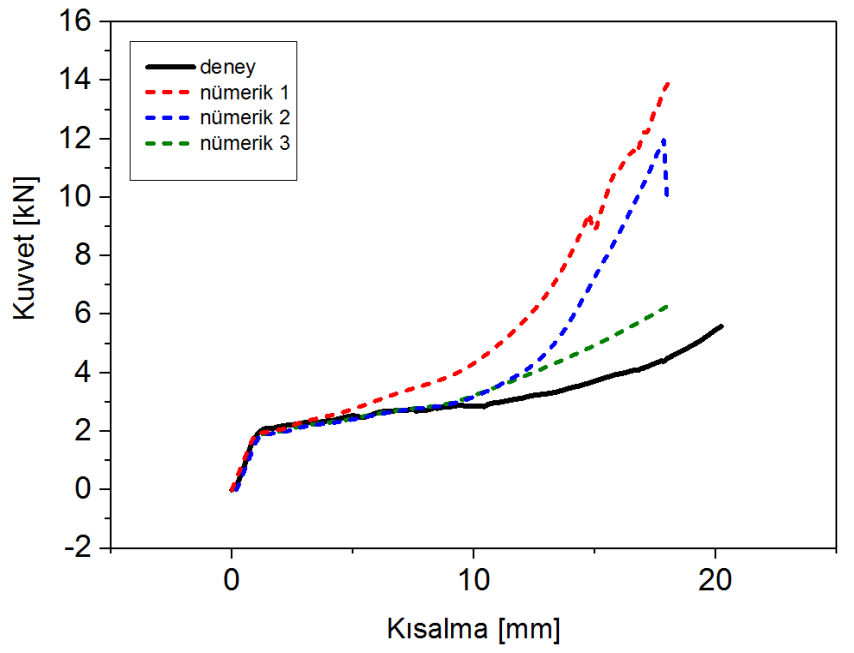

Şekil 4. Deneysel ve nümerik kuvvet-kısalma eğrileri (nümerik 1: gerçek gerilmegerçek gerinme, nümerik 2: nominal gerilme-gerçek gerinme, nümerik 3: nominal gerilme-gerçek gerinme <yoğunlaşma bölgesine kadar>). 


\subsection{Farklı oranlarda alüminyum köpük takviyeli çarpışma-kutularının çarpışma performansinin incelenmesi}

Farklı oranlarda (\%100, 80, 50 ve 30$)$ alüminyum köpük ile takviye edilmiș alüminyum kılıflı çarpışma-kutularının, köpük takviyesi yapılmamış çarpışma-kutusu ile karşılaştırılması için Abaqus/Explicit ile sanal çarpışma analizleri gerçekleştirilmiştir.

Şekil 5'te çarpışma-kutusunun çarpışma analizleri için oluşturulan sonlu elemanlar modeli verilmiştir. Çarpışma-kutusu, $100 \mathrm{~mm}$ x $50 \mathrm{~mm}$ boyutlarında dikdörtgen bir kesite ve 100 mm yüksekliğe sahip olacak şekilde modellenmiştir. Köpük malzemenin içerisine yerleştirildiği, et kalınlığ 2 mm olan kılıf malzemesi olarak alüminyum tanımlanmıştır. Kılıf, yüzey olarak modellenmiş ve elemanlara ayrılırken S4R yüzey elemanı kullanılmıştır. Kılıfın, gerinme hızına bağlı Johnson-Cook (J-C) malzeme özellikleri Tablo 2'de verilmiştir.

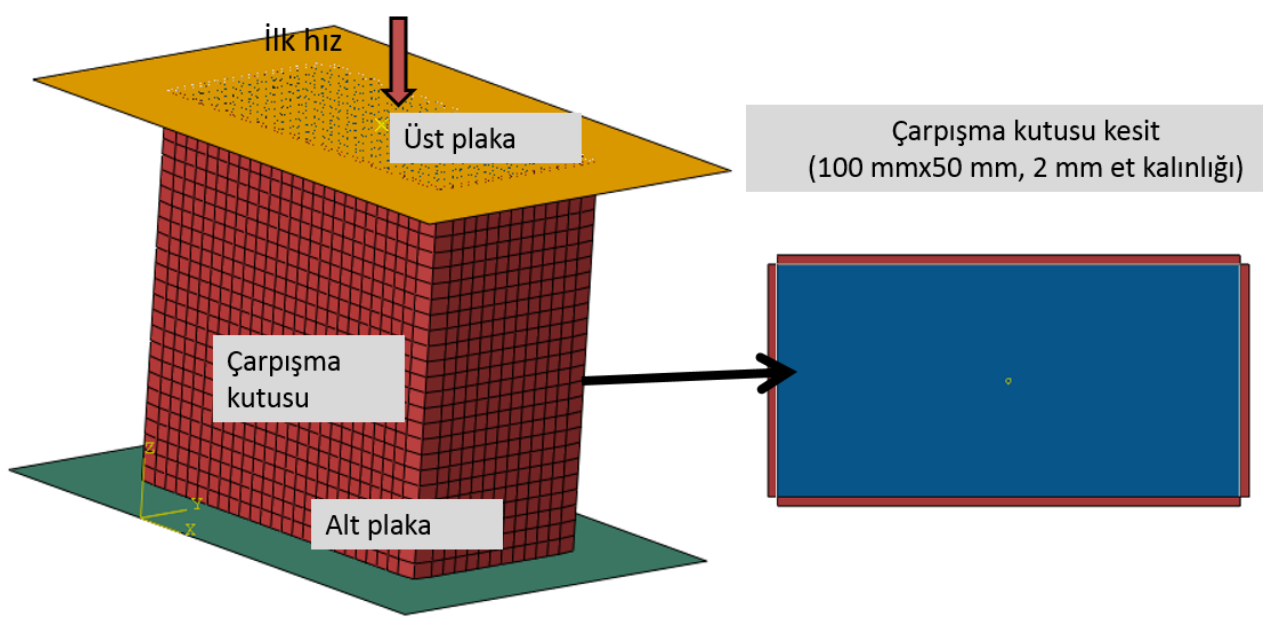

Şekil 5. Çarpışma analizleri için oluşturulan sonlu elemanlar modeli.

Tablo 2. Alüminyum k1lıfa ait Johnson-Cook sabitleri [20].

\begin{tabular}{|c|c|}
\hline Malzeme Sabitleri & Değer \\
\hline $\mathrm{A}[\mathrm{MPa}]$ & 111,82 \\
\hline $\mathrm{B}[\mathrm{MPa}]$ & 241,40 \\
\hline $\mathrm{n}$ & 0,415 \\
\hline $\mathrm{C}$ & 0,012 \\
\hline $\mathrm{m}$ & 1,003 \\
\hline
\end{tabular}

Katı olarak modellenen köpük malzemenin elemanlarına ayrılmasında C3D8R elemanı kullanılmıştır. Çarpışma-kutusunun üzerine konulduğu alt plaka ve kütlenin tanımlandığı üst plaka, analitik rijit olarak modellenmiş ve üst plakaya $570 \mathrm{~kg}$ 'llk çarpma kütlesi tanımlanmıştır. Kılıfın katlanması esnasında kendi içerisinde oluşacak kontaklar da göz önüne alınarak, Explicit genel kontak tüm model için tanımlanmıştır. Tüm modeller için 2-5 mm eleman boyutu kullanılmıştır. Analizde yakınsamama durumu söz konusu olunca eleman boyutu büyütülmüsstür.

Şekil 6 ve Şekil 7 incelenirse, boş çarpışma-kutusunun köpük ile takviye edilmiş çarpışma-kutularına göre daha düşük plato kuvveti ve çarpışma süresine sahip olduğu görülmektedir. Bu sebeple, boş çarpışma-kutusundaki son çarpışma kuvvetinin (final 
impact force), diğerlerindekine göre çok önemli oranda yüksek olduğu görülmektedir. Son çarpışma kuvveti, azalan doluluk oranıyla artmakta; plato kuvveti ise, tam tersi olarak düşmekte ve boş çarpışma-kutusunun değerine yaklaşmaktadır. Doluluk oranı arttıkça toplam yer değiştirme, yani çarpışma-kutusunun sıkıștırılabilirliği ise düșmektedir.
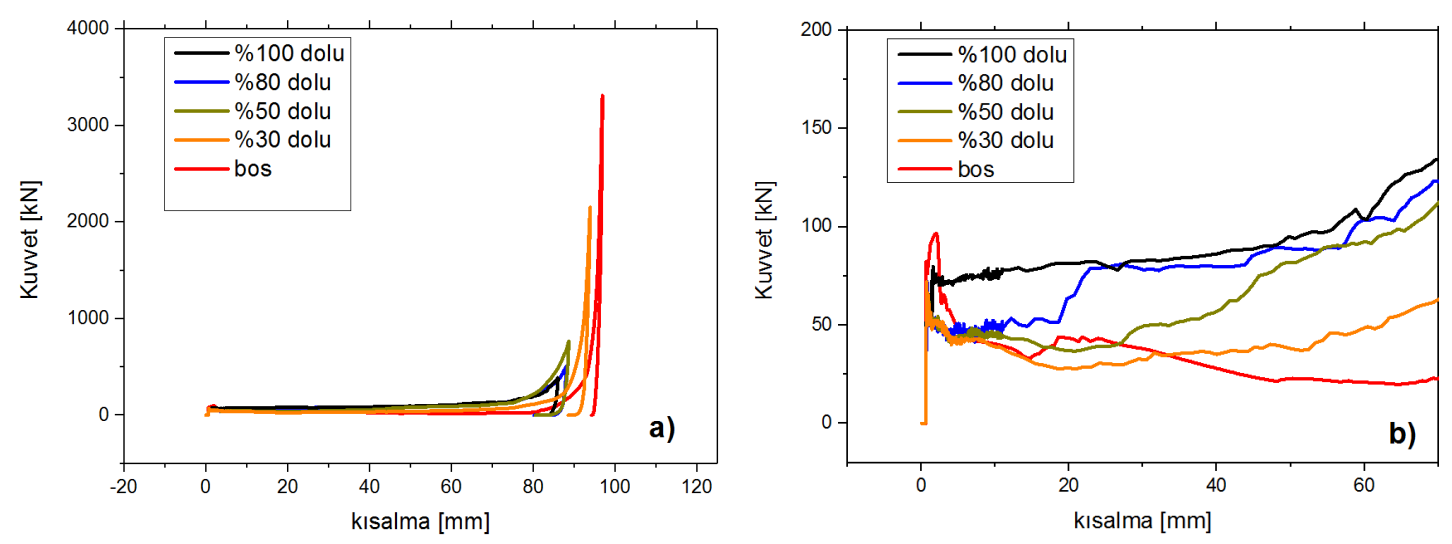

Şekil 6. Farklı doluluk oranlarına sahip çarpışma-kutularına ve boş çarpışma-kutusuna ait nümerik kuvvet-kısalma eğrileri: a) tüm çarpışma b) ilk çarpışma bölgesi.

Beklenildiği gibi, çarpışma-kutularının emdiği enerji miktarları, köpük doluluk oranı arttıkça artmaktadır. Kısmî dolu kutuların eğrileri tam dolu kutularınki ile karşılaştırılırsa; enerji emme hızının köpüksüz kısımda düşük olup, köpük dolu kısma ulaştığında daha yüksek olduğu görülmektedir.

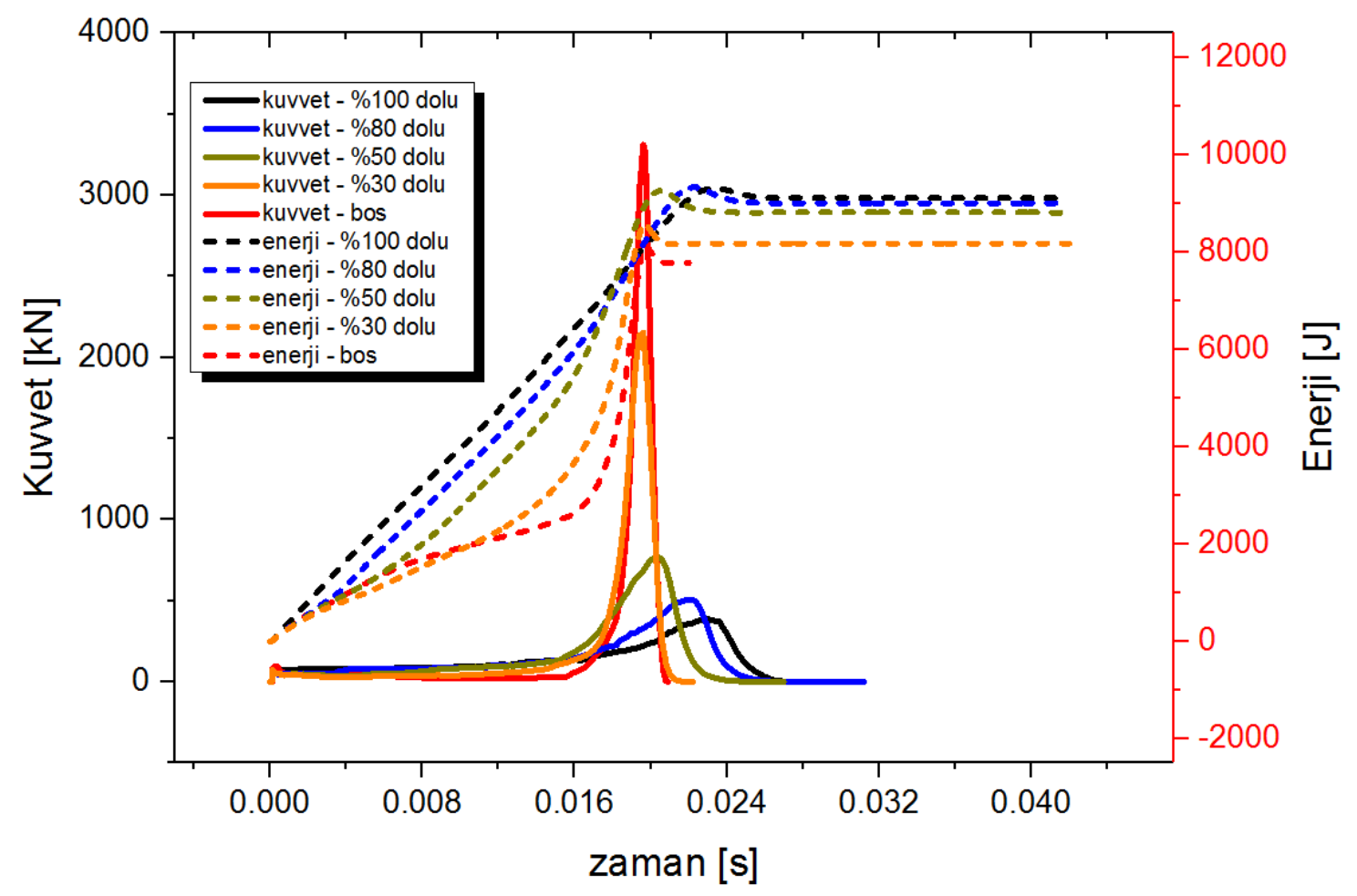

Şekil 7. Farklı doluluk oranlarına sahip çarpışma-kutularına ve boş çarpışma-kutusuna ait nümerik kuvvet-zaman ve enerji-zaman eğrileri. 


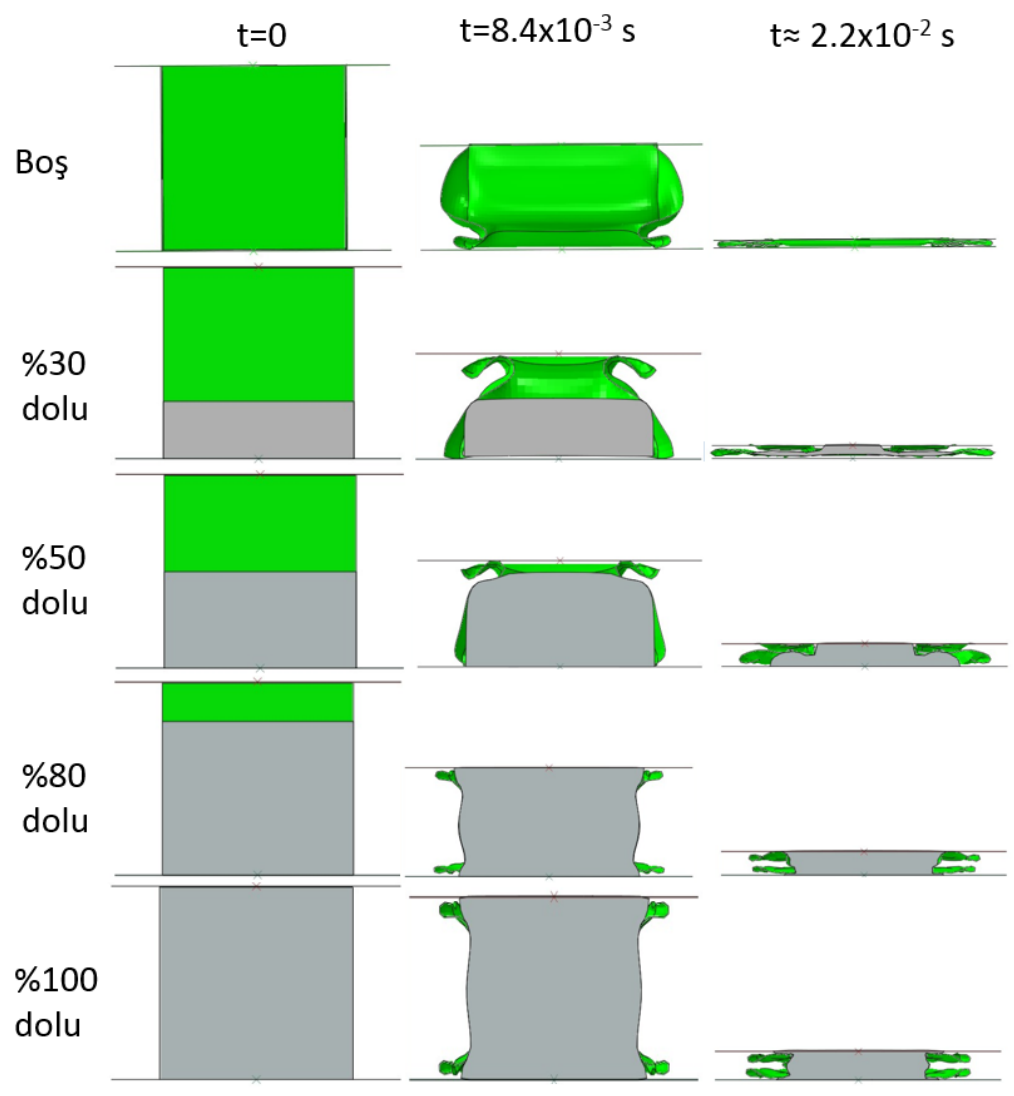

Şekil 8. Deformasyona uğramış çarpışma-kutuları (kesit görüntüleri).

Şekil 8'de deformasyona uğramış çarpışma-kutuları görülmektedir. $\% 100$ ve $\% 80$ doluluk oranlarında çarpışma-kutuları benzer şekilde deforme olurken, eşzamanlı olarak alttan ve üstten katlanma başlamaktadır. Boş çarpışma-kutusu aynı şekilde alttan katlanmaya başlarken, üst taraftan yanal olarak şişmektedir. \%30 ve \%50 dolu çarpışmakutuları ise üstten katlanmaya başlamakta, fakat alttan katlanma çarpışmanın sonuna doğru gerçekleşmektedir. Yoğunlaşma noktasından sonra köpüğün sıkıştırılabilmesi zorlaştı̆̆ için, çarpışma-kutusundaki köpük oranı arttıkça kısalma miktarları, yani son sıkıştırılabilme miktarları düşmektedir.

Emilen çarpışma enerjisi miktarının köpük oranına bağlı değişimi Şekil 9a' da verilmiştir. Köpük takviyesi ile birlikte enerji miktarı önemli oranda artmaktadır. Özellikle \%50 köpük oranına kadar, artış daha yüksek hızda olmaktadır. Araçlar için hafifliğin de önemli bir faktör olması nedeniyle, birim kütle başına enerji emilimi değeri olan özgül enerji emilimi (ÖEE) miktarları da hesaplanmıştır. Grafiğe göre (Şekil 9b), köpük oranı arttıkça özgül enerji emilimi değerinin düştüğü görülmektedir. Köpük takviyesinin bir miktar ağırlık artışına sebep olması kaçınılmazdır; fakat ağırlık en uygun seviyede tutularak, emilen çarpışma enerjisinde önemli artışlar yakalanabilmektedir. 

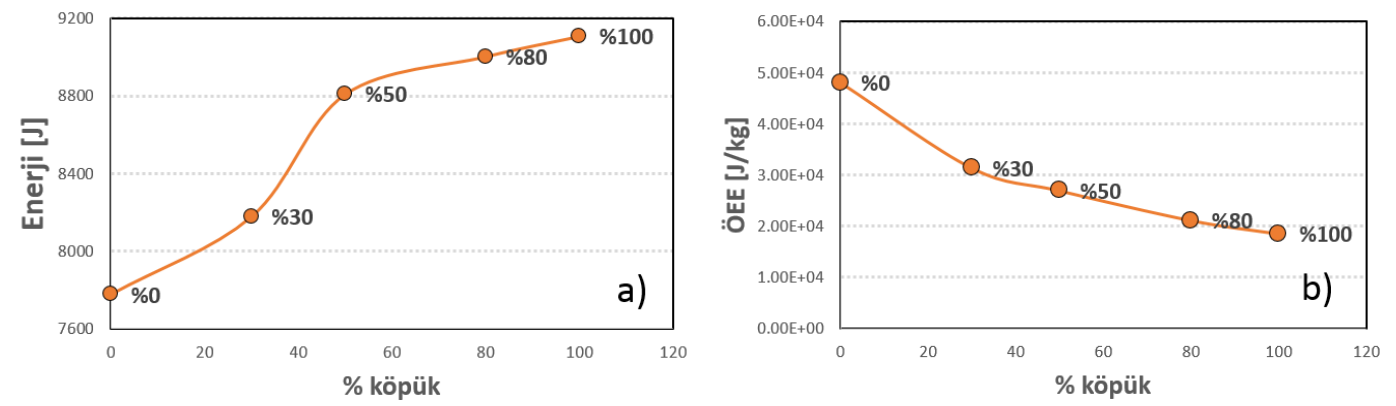

Şekil 9. Çarpışma-kutularının köpük doluluk oranına bağlı olarak (a) enerji emilimi (b) özgül enerji emilimi değerleri.

\section{Sonuçlar}

Bu çalışmada, öncelikle, alüminyum köpük malzemenin nümerik malzeme modelinin oluşturulması için yarı-statik basma testleri gerçekleştirilmiştir. Oluşturulan model, farklı oranlarda alüminyum köpük takviyesi yapılmış çarpışma-kutuları ile boş çarpışmakutusunun çarpışma performanslarının nümerik olarak incelenmesi için kullanılmıştır. Buna göre:

1. Boş çarpışma-kutusu en düşük plato kuvveti ve çarpışma süresine sahip olmakla birlikte, artan köpük takviyesi ile bu değerler artmaktadır. Bu nedenle, köpük oranının artmasına bağlı olarak emilen enerji miktarları da artmaktadır. Otomobil üreticilerinin önerdiği kuvvet değerlerini aşmamak kaydıyla, plato kuvveti değeri yüksek tutularak emilen enerji değerleri daha yüksek değerlere taşınabilir.

2. En yüksek köpük doluluk oranlarında, çarpışma-kutuları alttan ve üstten eşzamanlı katlanmayla deforme olurken; diğer az dolu kutularda, ilk olarak üstten katlanma başlayıp çarpışma sonunda alttan katlanma gerçekleşmektedir. Boş çarpışma-kutusunda ise, alttan katlanma oluşmakta fakat üstten yanal olarak şişme gerçekleşmektedir.

3. Boş çarpışma-kutusu, en yüksek kısalma (sıkıştırılabilme) değerine sahiptir. Köpük takviyeli kutularda, köpük oranı arttıkça bu değer düşmektedir.

4. Çarpışma-kutuları tarafından emilen enerji miktarları, artan köpük oranıyla birlikte artmaktadır. Özgül enerji emilimi değerleri ise, kütle artışına bağlı olarak bir miktar düşse de; çarpışma-kutusu kütlesi ve emilen enerji için optimum değerler göz önüne alınarak uygun köpük takviyesi oranları kullanılabilir.

\section{Kaynaklar}

[1] Kuznetcov A., Telichev I. ve Wu C.Q., Effect of thin-walled tube geometry on its crashworthiness performance, 14th International LS-DYNA Users Conference, Detroit, USA. 12-14 June, (2016).

[2] Nia A.A. ve Hamedani J.H., Comparative analysis of energy absorption and deformations of thin walled tubes with various section geometries, Thin-walled Structures, 48, 946-954,(2010).

[3] Boreanaz, M., Development of crash box for automotive application, Politecnico di Torino, Italy, (2018). 
[4] Rajak, D.P., Kumaraswamidhas, L.A. ve Das, S. , Technical overview of aluminium alloy foam, Reviews on Advanced Materials Science, 48, 68-86, (2017).

[5] İnce, F., Türkmen, H.S., Mecitoğlu Z., Uludağ N., Durgun, İ., Altınok, E. ve Örenel, H., A numerical and experimental study on the impact behavior of box structures, Procedia Engineering, 10, 1736-1741, (2011).

[6] Zhang, X. ve Cheng, G., A comparative study of energy absorption characteristics of foam-filled and multi-cell square columns, International Journal of Impact Engineering, 34, 1739-1752, (2007).

[7] Shahbeyk, S., Vafai, A. ve Petrinic, N., Axial crushing of metal foam-filled square columns:Foam density distribution and impactor inclination effects, Thin-Walled Structures, 43, 1818-1830, (2005).

[8] Gibson, L.J. ve Ashby, M.F., Cellular solids: structure and properties, Cambridge University Press, (1997).

[9] Ashby, M.F., Evans, A.G.,. Fleck, N.A, Gibson, L.J., Hutchinson, J.W. ve Wadley, H.N.G., Metal foams: a design guide, Butterworth-Heinemann, (2000).

[10] Kretz, R. ve Götzinger, B. Energy absorbing behaviour of aluminium foams: head impact tests on an a-pillar of a passenger car. Proceedings, the Cellular Metals and Metal Foaming Technology: Metfoam, 17-24, Bremen, (2001).

[11] Rabiei, A. ve Vendra, L.J., A comparison of composite metal foam's properties and other comparable metal foams, Materials Letters, 63, 533-536, (2009).

[12] Garcia-Moreno, F., Commercial applications of metal foams:their properties and production, Materials, 9, 85, 1-27 (2016).

[13] Fiedler, T., Taherishargh, M., Krstulović-Opara, L. ve Vesenjak, M., Dynamic compressive loading of expanded perlite/aluminum syntactic foam, Materials Science Engineering A, 626, 296-304, (2015).

[14] Sulong, M.A., Taherishargh, M., Belova, I.V., Murch, G.E. ve Fiedler, T., On the mechanical anisotropy of the compressive properties of aluminium perlite syntactic foam, Computatinal Materials Science, 109, 258-265, (2015).

[15] Balcha, D.K., O’Dwyerb, J.G., Davis, G.R., Cady, C.M., Gray, G.T. ve Dunand, D.C., Plasticity and damage in aluminum syntactic foams deformed under dynamic and quasi-static conditions, Materials Science Engineering A, 391, 408-417,(2005).

[16] ISO 13314, Compression Test for Porous and Cellular Metals, (2011).

[17] Deshpande, V.S. ve Fleck, N.A., Isotropic constitutive models for metallic foams, Journal of the Mechanics and Physics of Solids, 48, 1253-1283, (2000).

[18] ABAQUS User's Manual, Version 6.14. Providence, RI: Dassault Systemes Simulia Corp., (2014).

[19] Gülçimen, Ç.B. ve Ensarioğlu, C., Numerical modelling of aluminum foam for comparing foam-filled, partially foam-filled and empty crash-boxes, International Conference on Engineering Technologies (ICENTE'17), Konya/Turkey, (2017).

[20] Kruszka, L., Anaszewicz, Ł., Janiszewski, J. ve Grazka, M., Experimental and numerical analysis of Al6063 duralumin using Taylor impact test, EPJ Web of Conferences, 26, 01062, (2012). 